\title{
HUBUNGAN ANTARA KONSEP DIRI DENGAN KOMUNIKASI INTERPERSONAL YANG EFEKTIF ANTARA IBU DAN ANAK
}

\author{
Rozan Ismatul Maula Sofwan, Triana Noor Edwina D S \\ Fakultas Psikologi Universitas Mercu Buana Yogyakarta \\ ismaemaula@gmail.com
}

\begin{abstract}
Abstrak
Penelitian ini bertujuan untuk mengetahui hubungan antara konsep diri dengan komunikasi interpersonal yang efektif antara ibu dan anak pada masa remaja tengah. Hipotesis yang diajukan penelitian ini adalah terdapat hubungan antara konsep diri dengan komunikasi interpersonal yang efektif antara ibu dan anak. Semakin tinggi konsep diri subjek dalam penelitian ini maka semakin efektif komunikasi interpersonal dengan ibunya, sebaliknya semakin rendah konsep diri subjek maka semakin tidak efektif komunikasi dengan ibunya. Penelitian ini dilakukan di salah satu sekolah menengah atas di Daerah Istimewa Yogyakarta (DIY) dengan karakteristik subjek penelitian adalah remaja pada usia pertengahan yang berusia $15-18$ tahun yang tinggal bersama ibu. Pengumpulan data penelitian menggunakan skala konsep diri dan skala komunikasi interpersonal yang efektif antara ibu dan anak. Berdasarkan analisis data yang dilakukan, ditemukan ada hubungan antara konsep diri dengan komunikasi interpersonal yang efektif antara ibu dan anak pada masa remaja tengah. Koefisien korelasi antara konsep diri dengan komunikasi interpersonal yang efektif antara ibu dan anak sebesar rxy = $0,552(p<0,01)$.
\end{abstract}

Kata kunci: komunikasi interpersonal yang efektif; konsep diri; anak remaja pertengahan

\begin{abstract}
This study aims to determine the relationship between self-concept with effective interpersonal communication between mother and child during middle adolescence. The hypothesis of this research is that there is a relationship between self concept and effective interpersonal communication between mother and child. The higher the self concept of the subject in this study then the more effective interpersonal communication with his mother, on the contrary the lower the self concept of the subject then the more ineffective communication with his mother. This research was conducted in one high school in Yogyakarta Special Region (DIY) with research subject characteristic is adolescent at middle age aged 15 - 18 years who live with mother. Data collection research using self-concept scale and effective interpersonal communication scale between mother and child. Based on data analysis conducted, found there is relationship between self concept with effective interpersonal communication between mother and child during middle adolescence. The correlation coefficient between self concept and effective interpersonal communication between mother and child equal to $r x y=0,552(p<0,01)$.
\end{abstract}

Keywords: effective interpersonal communication, self concept, middle age adolescent 


\section{PENDAHULUAN}

Kehidupan manusia tidak bisa lepas dari sebuah komunikasi, baik yang bersifat verbal maupun nonverbal. Manusia melakukan proses komunikasi dengan lawan bicaranya baik di lingkungan masyarakat, tempat bekerja, sekolah, keluarga, maupun organisasi. Namun diantara lingkungan yang ada, keluargalah yang sangat mempengaruhi kehidupan seseorang dikarenakan intensitas dan frekuensinya yang cenderung tetap dan rutin. Oleh karenanya, Djamarah (2004) menyatakan bahwa komunikasi merupakan sesuatu yang esensial dalam kehidupan keluarga.

Komunikasi interpersonal merupakan komunikasi yang sering terjadi dalam keluarga (Djamarah, 2004). Komunikasi yang terjadi berlangsung dalam sebuah interaksi antarpribadi, antara suami dan istri, antara ayah dan anak, antara ibu dan anak, dan antara anak dan anak. Menurut Wood (2013) komunikasi interpersonal berasal dari kata inter yang berarti "antara" dan kata person yang berarti "orang", jadi komunikasi interpersonal secara umum diartikan sebagai komunikasi yang terjadi diantara dua orang. Devito (dalam Suciati, 2015) memaparkan bahwa komunikasi interpersonal adalah komunikasi yang terjadi diantara dua orang yang telah memiliki hubungan yang jelas, yang terhubungkan dengan beberapa cara. Selanjutnya Devito (dalam Suciati, 2015) menguraikan bahwa terdapat lima ciri dari komunikasi interpersonal yaitu, keterbukaan, empati, sikap mendukung, sikap positif, dan kesetaraan.

Djamarah (2004) menguraikan bahwa keinginan anak untuk berbicara dengan orang tuanya dari hati ke hati melahirkan komunikasi interpersonal. Peranan orang tua, baik ayah maupun ibu sama-sama pentingnya walaupun pada kenyataannya menunjukkan bahwa ibu lebih besar peranannya dalam proses regenerasi dan perkembangan kepribadian anak. Selain itu pada umumnya ibu bersikap lebih menerima, lebih mengerti, dan lebih kooperatif terhadap anak remajanya dibandingkan dengan ayah (Monks dkk, 2006). Oleh karenanya, menurut Sputta \& Paulson (Santrock, 2007) menyatakan dalam proses perkembangan ibu memiliki keterlibatan yang lebih besar dalam pengasuhan.

Namun pada kenyataannya kegiatan komunikasi antara ibu dan anak semakin berkurang. Fenomena yang terjadi saat ini menunjukkan bahwa sebagian besar orang tua lebih banyak mengutamakan pekerjaan daripada berinteraksi di rumah. Berdasarkan data statistik BPS (2011) menyatakan bahwa dari 100\% wanita, $82 \%$ adalah wanita bekerja dan sisanya sebanyak $17,31 \%$ adalah tidak bekerja. Perilaku di atas disebabkan adanya anggapan bahwa memenuhi kebutuhan materil anak penting dalam mempertahankan diri ditengah kerasnya roda perekonomian. Dengan anggapan, orang tua terutama seorang ibu cenderung mengesampingkan pentingnya sebuah kualitas interaksi antara anak dan orang tua atau dalam bentuk konkritnya adalah sebuah komunikasi interpersonal. 
Djamarah (2004) menuturkan bahwa orang tua harus proaktif untuk mengawali pembicaraan, jangan memaksa anak untuk memahami dunia orang tua, berpikir dan berperilaku seperti orang tua. Jika hal itu terjadi, maka komunikasi antara orang tua dan anak tidak dapat berlangsung dengan baik dan efektif, khususnya komunikasi antara ibu dan anak.

Adapun penelitian tentang fenomena remaja di Kabupaten Gresik (Mudlofar dalam Ginting, 2009) menyebutkan bahwa di tahun 2006, terdapat kasus narkoba, dari jumlah tersebut, 7 diantaranya ialah pelajar. Penyebab utamanya ialah konflik sosial yang mencapai angka $87,4 \%$, khususnya diakibatkan dari adanya konflik dengan orang tua yang ditunjukkan dengan angka 40,5\%. Data hasil penelitian tersebut juga mengungkapkan apa saja yang dilakukan remaja dalam upaya mengurangi bebas psikologis akibat narkoba. Upaya-upaya yang dilakukan mereka antara lain: curhat kepada teman atau sahabat $(76 \%)$, baru kemudian mereka mengemukakan pada pacar $(12 \%)$, kepada orang tua $(2,8 \%)$, dan menyampaikan pada guru mencapai $(1,1 \%)$. Dari data tersebut, persentase keterbukaan remaja pada orang tua hanya mencapai titik $2,8 \%$.

Peneliti juga melakukan wawancara pada 10 orang remaja pada masa pertengahan dengan kisaran usia 15 - 18 tahun yang tinggal bersama ibunya, wawancara dilakukan pada tanggal 17 September dan 2 Desember 2015. 7 dari 10 remaja menyatakan bahwa komunikasi dengan ibu hanya sebatas lingkup aktivitas sehari-hari seperti kegiatan sekolah, namun mengenai masalah pribadi, masalah di sekolah, masalah dengan pasanagan atau teman, tidak dibicarakan dengan ibu. Dengan demikian subyek dalam hal berkomunikasi interpersonal dengan ibunya tidak bersifat efektif karena tidak mengandung adanya keterbukaan, empati, sikap mendukung, sikap positif, dan kesetaraan. Adapun 3 remaja sisanya menyatakan bahwa ibu merupakan satu-satunya orang yang menjadi tempat paling nyaman untuk membicarakan hal apapun dalam kehidupannya.

Fenomena di atas membuktikan bahwa tampaknya komunikasi interpersonal ibu dan anak terjalin kurang efektif. Seharusnya komunikasi interpersonal harus terjalin secara efektif dengan adanya keterbukaan, saling berempati, saling mendukung, saling memberikan rasa positif, dan saling memiliki rasa kesetaraan (Devito dalam Suciati, 2015).

Komunikasi interpersonal antara ibu dan anak yang efektif sangat diperlukan untuk mengetahui perkembangan remaja dan permasalahan-permasalahan yang sedang dialami oleh remaja. Tidak efektifnya komunikasi interpersonal antara ibu dan anak memberikan dampak negatif pada perkembangan anak. Shek (Lestari, 2012) menyatakan bahwa komunikasi orang tua dan anak dapat mempengaruhi fungsi keluarga secara keseluruhan dan kesejahteraan psikososial pada diri anak.

Rakhmat (2007) menyatakan faktor yang dapat mempengaruhi keberhasilan komunikasi interpersonal meliputi; faktor persepsi interpersonal, konsep diri, atraksi interpersonal, dan hubungan interpersonal. Diantara ke empat faktor yang mempengaruhi 
komunikasi interpersonal, maka penelitian ini menitik beratkan pada konsep diri. Hal tersebut karena Rakhmat (2015) mengatakan konsep diri merupakan faktor yang menentukan dalam komunikasi interpersonal, karena setiap orang bertingkah laku sedapat mungkin sesuai dengan konsep dirinya.

Calhaun dan Acocella (Desmita, 2012) menyatakan bahwa konsep diri adalah pandangan diri sendiri yang meliputi tiga dimensi yakni pengetahuan tentang diri sendiri, harapan tentang diri sendiri, dan penilaian tentang diri sendiri. kemudian Cawagas (Desmita, 2012) menjelaskan bahwa konsep diri mencakup seluruh pandangan individu akan dimensi fisiknya, karakteristik pribadinya, motivasinya, kelemahannya, kelebihan atau kecakapannya, kegagalannya, dan sebagainya.

Calhaun dan Acocella (Desmita, 2012) menyatakan bahwa terdapat tiga dimensi dari konsep diri, yaitu; pengetahuan, yakni penjelasan mengenai gambaran diri yang mencakup segala sesuatu yang kita pikirkan tentang diri kita sebagai pribadi; harapan, yakni harapan atau diri yang dicita-citakan (self ideal); dan penilaian, yakni pandangan kita mengenai harga atau kewajaran kita sebagai pribadi.

Menurut Rita (2009) secara teoritis konsep diri menjadi salah satu faktor yang berhubungan dengan komunikasi interpersonal. Begitu juga dengan Rakhmat (2015) yang menyatakan bahwa suksesnya komunikasi interpersonal banyak bergantung pada kualitas konsep diri. Remaja dengan konsep diri yang tinggi dapat menghasilkan komunikasi interpersonal yang efektif dalam hubungan dengan ibunya. Individu yang memiliki pengetahuan mengenai dirinya akan meningkatkan keterbukaan dalam berkomunikasi. Kemudian individu yang mampu menilai dan menerima dirinya yang baik maupun yang buruk serta adanya keinginan untuk memperbaiki dan mencapai diri idealnya akan melahirkan komunikasi interpersonal. Dengan demikian, semakin tinggi konsep diri remaja maka akan semakin efektif komunikasi interpersonal dengan ibunya. Sebaliknya semakin rendah konsep diri remaja maka akan semakin kurang efektif komunikasi interpersonal dengan ibunya.

Berdasarkan uraian di atas, hipotesis yang diajukan dalam penelitian ini adalah terdapat hubungan antara konsep diri dengan komunikasi interpersonal yang efektif antara ibu dan anak. Semakin tinggi konsep diri maka semakin efektif komunikasi interpersonal antara ibu dan anak, sebaliknya semakin rendah konsep diri maka semakin tidak efektif komunikasi interpersonal antara ibu dan anak.

\section{METODE PENELITIAN}

Subjek dalam penelitian ini adalah remaja dengan kriteria berusia 15 - 18 tahun, pada masa usia tersebut merupakan masa krisis yaitu suatu masa dengan gejala-gejala krisis yang menunjukkan adanya pembelokan dalam perkembangan, suatu kepekaan dan labilitas meningkat (Monks, dkk 2006), kemudian tinggal dengan ibu. Subjek dalam penelitian ini 
berjumlah 110 orang siswa dengan keteragan 54 orang yang digunakan dalam try out dan 56 orang yang digunakan dalam penelitian.

Metode pengumpulan data dalam penelitian ini menggunakan metode skala, yaitu skala konsep diri yang disusun berdasarkan dimensi konsep diri dan skala komunikasi interpersonal yang efektif antara ibu dan anak yang disusun berdasarkan ciri-ciri komunikasi interpersonal yang efektif.

Metode skala pada penelitian ini menggunakan skala model Likert dengan 4 alternatif jawaban, yaitu: sangat sesuai (SS), sesuai (S), tidak sesuai (TS), dan sangat tidak sesuai (STS). Modifikasi dengan 4 alternatif jawaban yang dilakukan peneliti adalah untuk menghilangkan kategori belum memutuskan (undecided) yang mempunyai arti belum dapat memutuskan. Jawaban netral pada pernyataan skala tidak digunakan karena jawaban netral akan berpengaruh pada baik tidaknya suatu pernyataan mengungkap aspek-aspek tertentu (Azwar, 2012).

Sebelum digunakan dalam penelitian, alat ukur terlebih dahulu dilakukan uji coba untuk mengetahui kualitas skala yang meliputi uji validitas (daya beda aitem) dan uji reliabilitas Skala konsep diri dan komunikasi interpersonal yang efektif antara ibu dan anak. Nilai koefisien korelasi yang tinggi akan menunjukkan kesesuaian antara fungsi-fungsi aitem dan fungsi alat ukur secara keseluruhan. Batas koefisien $\geq 0,200$ sudah dapat diterima untuk dipakai dalam penelitian (Azwar, 2012). Sedangkan aitem yang memiliki koefisien validitas kurang dari angka tersebut dianggap gugur.

Berdasarkan analisa uji coba Skala Konsep Diri yang terdiri dari 30 aitem, 26 aitem yang valid dan 4 aitem yang tidak valid. Koefisien validitas aitem bergerak dari 0,231 sampai 0,646. Koefisien reliabilitas berkisar antara 0 sampai dengan 1,00 (Azwar, 2012). Pada analisis hasil uji coba Skala Konsep Diri diperoleh angka koefisien reliabilitas sebesar 0,870. Hal tersebut menunjukkan bahwa skala Konsep Diri memiliki tingkat keajegan dan keandalan sebesar $87 \%$ dan menampakan variansi eror sebesar $13 \%$. Adapun skala komunikasi interpersonal terdiri dari 50 aitem, 41 aitem yang valid dan 9 aitem tidak valid. Koefisien validitas aitem bergerak dari 0,237 sampai dengan 0,824. Adapun pada analisis hasil uji coba Skala Komunikasi Interpersonal yang Efektif antara Ibu dan Anak diperoleh angka koefisien reliabilitas sebesar 0,926. Hal tersebut menunjukkan bahwa skala Komunikasi Interpersonal yang Efektif antara Ibu dan Anak memiliki tingkat keajegan dan keandalan sebesar 92,6\% dengan variansi eror sebesar 7,4\%.

Metode analisis data yang digunakan dalam penelitian ini adalah melalui uji korelasi product moment dari Pearson. 


\section{HASIL DAN PEMBAHASAN}

Uji normalitas dilakukan menggunakan teknik (Kolmogorv-Smirnov). Hasil uji normalitas sebaran data Komunikasi Interpesonal yang Efektif antara Ibu dan Anak menunjukkan nilai KS-Z sebesar 0,086 dengan taraf signifikansi 0,200 ( $p>0,05)$, kemudian hasil uji normalitas sebaran data Konsep Diri menunjukkan nilai KS-Z sebesar 0,060 dengan taraf signifikansi sebesar 0,200 ( $p>0,05)$. Berdasarkan uji normalitas dapat disimpulkan bahwa data komunikasi interpersonal yang efektif antara ibu dan anak serta data konsep diri yang terkumpul telah terdistribusi mengikuti bentuk kurve normal.

Uji linieritas dilakukan untuk mengetahui linier tidaknya hubungan antara kedua variabel dalam penelitian ini (konsep diri dengan komunikasi interpersonal yang efektif antara ibu dan anak). Data tiap variabel diuji linieritas dengan menggunakan teknik Test of Linierity. Suatu data dikatakan linier apabila $p<0,05$ (Hadi, 2001). Hasil uji linieritas variabel konsep diri dan komunikasi interpersonal yang efektif antara ibu dan anak menunjukkan nilai koefisien linier $F$ sebesar 25,513 dengan taraf signifikansi sebesar 0,000 $(p<0,05)$. Berdasarkan analisis tersebut dapat diambil kesimpulan bahwa ada hubungan yang linier antara konsep diri dengan komunikasi interpersonal yang efektif antara ibu dan anak.

Pengujian hipotesis dalam penelitian ini menggunakan teknik analisis korelasi product moment yang dilakukan terhadap data konsep diri dan komunikasi interpersonal yang efektif antara ibu dan anak diperoleh koefisien sebesar 0,552 dengan taraf signifikansi $0,000(p<$ $0,01)$. Hal ini menunjukkan hipotesis yang menyatakan adanya hubungan positif antara konsep diri dengan komunikasi interpersonal yang efektif antara ibu dan anak dapat diterima. Semakin tinggi konsep diri maka akan semakin efektif komunikasi interpersonal ibu dan anak, sebaliknya semakin rendah konsep diri akan menyebabkan tidak efektifnya komunikasi interpersonal antara ibu dan anak.

Hasil penelitian menunjukkan adanya hubungan positif antara konsep diri dengan komunikasi interpersonal yang efektif antara ibu dan anak. Korelasi antara konsep diri dengan komunikasi interpersonal yang efektif antara ibu dan anak ditunjukkan dengan koefisien korelasi ( $r x y)$ sebesar 0,552 ( $p<0,01$ ). Hal ini menunjukkan bahwa hipotesis yang diajukan dapat diterima secara empirik yaitu ada hubungan positif antara konsep diri dengan komunikasi interpersonal yang efektif antara ibu dan anak. Hal tersebut mengandung arti bahwa semakin tinggi konsep diri maka semakin efektif komunikasi interpersonal antara ibu dan anak.

Hasil penelitian ini senada dengan pendapat yang dikemukakan oleh Rita (2009) bahwa salah satu faktor yang berhubungan dengan komunikasi interpersonal adalah konsep diri. Taylor (Rakhmat, 1994) menyatakan bahwa Konsep diri mempengaruhi perilaku komunikasi karena konsep diri mempengaruhi kepada pesan apa kita bersedia membuka diri, bagaimana kita mempersepsi pesan itu, dan apa yang kita ingat. Secara teoritis Fitts 
(Agustiani, 2006) mengemukakan bahwa konsep diri penting dalam diri individu karena konsep diri seseorang merupakan kerangka acuan (frame of reference) dalam berinteraksi dengan lingkungan.

Konsep diri merupakan faktor yang menentukan dalam komunikasi interpersonal, karena setiap orang bertingkah laku sedapat mungkin sesuai dengan konsep dirinya (Rakhmat, 2015). Komunikasi interpersonal yang bersifat efektif antara ibu dan anak tercipta apabila dalam prosesnya ibu dapat menyampaikan apa yang ingin disampaikan dan dapat diterima dan dimengerti dengan baik oleh anak. Komunikasi interpersonal yang efektif antara ibu dan anak terwujud apabila kedua belah pihak terdapat saling terbuka, empati, saling mendukung, saling bersikap positif, dan kesetaraan (De Vito, dalam Suciati 2015). Terciptanya komunikasi interpersonal ibu dan anak dapat menjamin anak remaja tidak mudah frustasi, dan kesulitan dalam menyesuaikan diri dalam kehidupan bermasyarakat (Iryani, 2009).

Menurut Calhaun dan Acocella (Desmita, 2012) konsep diri terdiri dari beberapa dimensi mencakup pengetahuan, harapan dan penilaian. Pengetahuan tentang diri akan meningkatkan komunikasi individu dengan orang lain. Apabila individu meyakini nilai-nilai dirinya yang baik maupun yang kurang baik dan menerimanya serta mampu memperbaiki dirinya karena sanggup mengungkapkan aspek-aspek kepribadian yang tidak disenanginya dan berusaha mengubahnya, maka ia akan mampu membuka diri kepada orang lain dengan tanpa ada keinginan untuk menutup diri sehingga ia tidak akan menghindari situasi komunikasi interpersonal (Rakhmat, 1994). Harapan merupakan diri ideal (self ideal) atau diri yang dicita-citakan yang terdiri atas dambaan, aspirasi, harapan, keinginan bagi diri kita atau menjadi manusia seperti apa yang kita inginkan. Cita-cita diri menentukan konsep diri dan konsep diri menjadi faktor paling penting dalam menentukan perilaku (Rakhmat, 2015). Adanya keinginan untuk memperbaiki dan mencapai diri idealnya akan membutuhkan dan melahirkan sikap dukungan positif dengan sikap saling menerima. Oleh karena itu remaja akan mampu untuk berkomunikasi dengan ibunya secara efektif atas kesadaran dirinya, karena semakin mengetahui dan menyadari akan dirinya sendiri dan orang lain maka akan semakin akrab hubungannya dengan orang tersebut. Dimensi terakhir dari konsep diri ialah penilaian.

Dimensi terakhir yakni penilaian. Penilaian yang dimaksud ialah pandangan kita tentang harga atau kewajaran kita sebagai pribadi yang terdiri atas pengharapan bagi diri sendiri dan standar yang kita tetapkan bagi diri kita sendiri. Semakin positif anak remaja menilai dirinya sendiri maka semakin baik konsep diri remaja tersebut. Remaja yang menilai dirinya dengan positif dalam artian ia percaya akan kemampuan dirinya maka ia tidak akan menghindari diri dari situasi komunikasi (Rakhmat, 2015). Dengan demikian, remaja yang memiliki penilaian yang positif terhadap diri sendiri dan menganggap kelemahan serta 
kelebihan dimiliki oleh semua orang, maka akan terbentuk perilaku komunikasi yang efektif dengan ditandai tidak menutup diri atau menarik diri saat berinteraksi dengan ibunya sehingga keterbukaan, sikap positif, kesetaraan, dan empati dalam berkomunikasi tercipta.

Berdasarkan hasil penelitian dapat diambil kesimpulan bahwa terdapat hubungan yang positif antara konsep diri dengan komunikasi interpersonal yang efektif antara ibu dan anak. Hal tersebut menunjukkan bahwa semakin tinggi konsep diri maka semakin efektif komunikasi interpersonal antara ibu dan anak, sebaliknya semakin rendah konsep diri maka semakin tifak efektif komunikasi interpersonal antara ibu dan anak. Komunikasi interpersonal yang efektif antara ibu dan anak tidak mutlak dipengaruhi oleh konsep diri karena masih ada variabel lain yang mempengaruhi komunikasi interpersonal yang efektif antara ibu dan anak.

\section{SIMPULAN}

1. Kesimpulan

Berdasarkan hasil penelitian dan pembahasan yang telah dilakukan, maka dapat disimpulkan bahwa ada hubungan positif antara konsep diri dengan komunikasi interpersonal yang efektif antara ibu dan anak. Koefisien korelasi antara konsep diri dengan komunikasi interpersonal yang efektif antara ibu dan anak sebesar $r x y=0,552(p<0,01)$. Hal ini menunjukkan bahwa semakin tinggi konsep diri maka semakin efektif komunikasi interpersonal antara ibu dan anak, sebaliknya semakin rendah konsep diri maka akan semakin tidak efektif komunikasi interpersonal antara ibu dan anak. Seseorang yang memandang dirinya secara positif akan menghasilkan konsep diri yang tinggi sehingga komunikasi interpersonal dengan ibunya akan terjalin dengan efektif.

\section{Saran}

Kepada ibu sebagai orang tua, dalam berkomunikasi sehari-hari dengan anak hendaknya tetap terbuka dalam membicarakan segala hal, mengungkapkan dan mengekspresikan empati, dukungan (verbal dan non verbal), bersikap positif pada anak sehingga anak merasakan kasih sayang dan perhatian yang diberikan, serta selalu berada setara dengan anak (tidak adanya otoritas atau superioritas) begitu pula sebaliknya, anak juga harus melakukan hal yang sama sehingga komunikasi interpersonal yang sudah tercipta dengan efektif antara ibu dan anak dapat terjaga dan dapat dipertahankan.

Bagi peneliti berikutnya disarankan untuk melakukan penelitian lanjutan dengan memperhatikan faktor lain yang berpengaruh terhadap komunikasi interpersonal yang efektif antara ibu dan anak. Faktor-faktor lainnya tersebut ialah persepsi interpersonal, atraksi interpersonal, dan hubungan interpersonal. 


\section{DAFTAR PUSTAKA}

Azwar, S. (2012). Penyusunan Skala Psikologi . Yogyakarta: Pustaka Pelajar.

Desmita. (2012). Psikologi Perkembangan Peserta Didik. Bandung: Remaja Rosda karya.

Djamarah, S. B. (2004). Pola Komunikasi orang Tua \& Anak dalam Keluarga: Sebuah Perspektif Pendidikan Islam. Jakarta: PT Rineka Cipta.

Ginting, J. K. (2009). Perbedaan Kualitas Komunikasi Orangtua dan Remaja Ditinjau dari Status Tempat Tinggal. Skripsi. Yogyakarta: Universitas Mercu Buana Yogyakarta.

Iryani, S. W. (2009). Membangun Keharmonisan Keluarga Meredam Kenakalan Remaja. Cetakan ke 1. Yogyakarta: B2P3KS Press.

Lestari, P. A. (2012). Hubungan Antara Konsep Diri dengan Komunikasi Interpersonal Siswa SMA (X) Yogykarta. Skripsi. Yogyakarta: UII.

Monks, F. J., Knoers, A. M. P., Haditono, S.R. (2006). Psikologi Perkembangan Pengantar Dalam Berbagai Bagiannya. Yogyakarta: Gadjah Mada University Press.

Rakhmat, J. (2007). Psikologi Komunikasi. Bandung: PT. Rosda Karya.

Rakhmat, J. (2015). Psikologi Komunikasi. Bandung: Remaja Rosda Karya.

Rakhmat, J. (1994). Psikologi Komunikasi. Edisi revisi. Bandung: PT. Remaja Rosda Karya.

Rita. (2009). Pola Asuh orangtua. Bandung: Remaja Rosda Karya.

Santrock, J. W. (2007). Remaja. Edisi kesebelas Jilid II. Jakarta: Erlangga.

Suciati. (2015). Komunikasi Interpersonal: Sebuah Tinjauan Psikologis dan Perspektif Islam. Yogyakarta: Buku Litera.

Wood, T. J. (2013). Komunikasi Interpersonal Interaksi Keseharian. Edisi 6. Jakarta: Salemba Humanika. 